Krystyna Michałowska*, Ewa Głowienka-Mikrut**, Sławomir Mikrut **, Mateusz Bochenek

\title{
Updating, Integration and Making Available Spatial Data with the Use of the State-of-the-Art Technologies ${ }^{* * *}$
}

\section{Introduction}

Nowadays, each local administration unit has the task of developing systems of monitoring and modelling of spatial data $[3,5,6,16]$. This has to accelerate the future predicting of floods and determining the endangered zones, which may need to be evacuated $[2,17]$. Collecting of data provides an opportunity for making spatial analyses [13, 15]. Monitoring of changes in surface waters is of special significance for the correct operation of the flood prevention system within the county, and not only there. An efficient meteorological and hydrological monitoring is based, first of all, on topographic maps [14]. The lie of the land (knowledge of river valley forms), as well as other hydrological factors constitute grounds for the simulation of the reach of the high-water flood wave [7]. It should also be remembered that when water in river beds rises, rivers begin to behave as "communicating tubes." The level of water rises in a given place, yet the surplus of water may overflow in quite another venue. The place in which a natural disaster is likely to occur is hard to determine [4]. In the case of a flood, a disaster may occur in any place, and its results depend on, among other things, the condition of the hydrotechnical infrastructure (resistance of flood control banks), numbers and volumes of flood control reservoirs, as well as other elements) [2].

Developing a model, which would become the basis for the performance of flood tests, or which could be applied even during the actual flood, is very expensive. It is the open-source software that makes an effort to meet our needs, since its

* University of Agriculture in Krakow, Poland

** AGH University of Science and Technology, Faculty of Mining Surveying and Environmental Engineering, Krakow, Poland

*** This paper has been prepared within the scope of the AGH UST statutory research no. 11.11 .150 .949 
functionality equals that of many commercial solutions, and, moreover, it is totally free of any charge.

\section{Study Area}

The Commune of Dębica is located in the north-west part of the Podkarpackie province of Poland and in the east and north-west parts of the Dębicki County (Fig. 1). The Commune of Dębica is composed of 19 villages. The seat of the Commune's administrative authorities is the town of Dębica. The Commune of Dębica has nowadays 24,488 inhabitants, and the population density of 175 persons per $1 \mathrm{~km}^{2}$. The Commune's surface area is 113,787 ha.

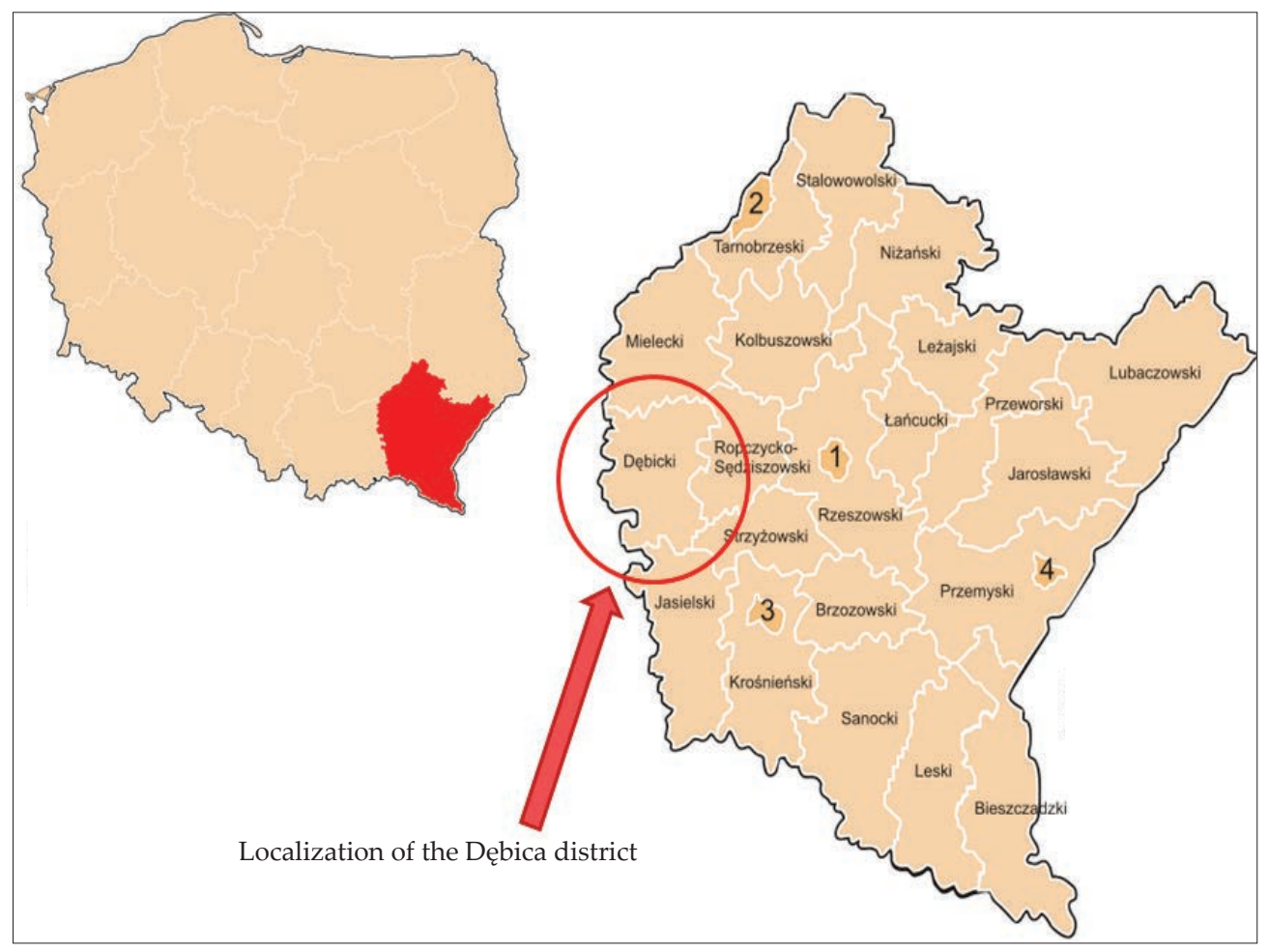

Fig. 1. Project area (1-4-towns as the administrative districts)

The area of the Commune lies within the borderland of two macroregions. The first of them, Sandomierz Basin on the north, which includes the mesoregion of the Lower Wisłoka River Valley, and the second, Central Beskidian Piedmont on the south, which includes the mesoregion of Strzyżów Piedmont [16]. The project 
area belongs to the Tarnów-Rzeszów climatic region of Poland. It is marked by a relatively frequent occurrence of very warm days, with precipitations (34 days in a year, on the average) [18]. Weather and climate are influenced by the direction of the flow of air masses, soil moisture, altitudes and forest areas [12].

In terms of hydrography, the area of the Commune of Dębica and its surroundings form part of the Wisłoka river basin, through a system of local ditches and streams.

\section{Spatial Data}

The following spatial data from the area of the rural Commune of Dębica were assumed for the project purposes:

- data of the regional authority for land improvement, melioration and water facilities in Rzeszów, Inspectorate in Dębica (Podkarpacki Zarząd Melioracji i Urządzeń Wodnych w Rzeszowie, Inspektorat Dębica) - database in MDB format, saved as BazaPZMiUW.mdb, orthophotomaps and topographic maps of the area under consideration (system '92 - EPSG:2180);

- data obtained from direct field measurements, saved in ESRI Shape File vector format (system WGS84 - EPSG:4326);

- vector data in the form of a file: debica-openstreet.osm, downloaded from the Website http://www.openstreetmap.org (system WGS84 - EPSG:4326);

- digital cadastral map, obtained from the County Office in Dębica, in DXF format (file: gm_Dębica.dxf) in 2000 system;

- vector data downloaded from the WFS Website, available through www.geoportal.gov (system '92 - EPSG:2180).

The project made use also of data that are generally available on the Internet. The Website: http://download.geofabrik.de contains data that are updated on a current basis, which can be downloaded for any place in the world. The main data format is ESRI Shapefile standard.

Initially, the data were collected for the area of Poland. The set of downloaded data included the following:

- buildings,

- land surface elements (e.g. arable land, orchards, residential areas, airfields, cemeteries, allotments, and other),

- points of interest (e.g. restaurants, shops, bus stops, petrol stations, crossroads, as well as other objects and facilities that have been recorded),

- nature (e.g. forests, parks, lakes, etc.),

- localities,

- railways,

- roads,

- rivers. 
Data concerning water courses were obtained through direct field measurements, conducted in October and November, 2012. Measurements covered water courses flowing to the Zawadka river. The location of the measured water courses is shown in Figure 2. GPS MobileMapper 6 receiver by Aschtech was used to perform measurements.

The results of the GPS measurements of rivers and water courses made it possible to precisely spot them, and to outline their riverbed courses.

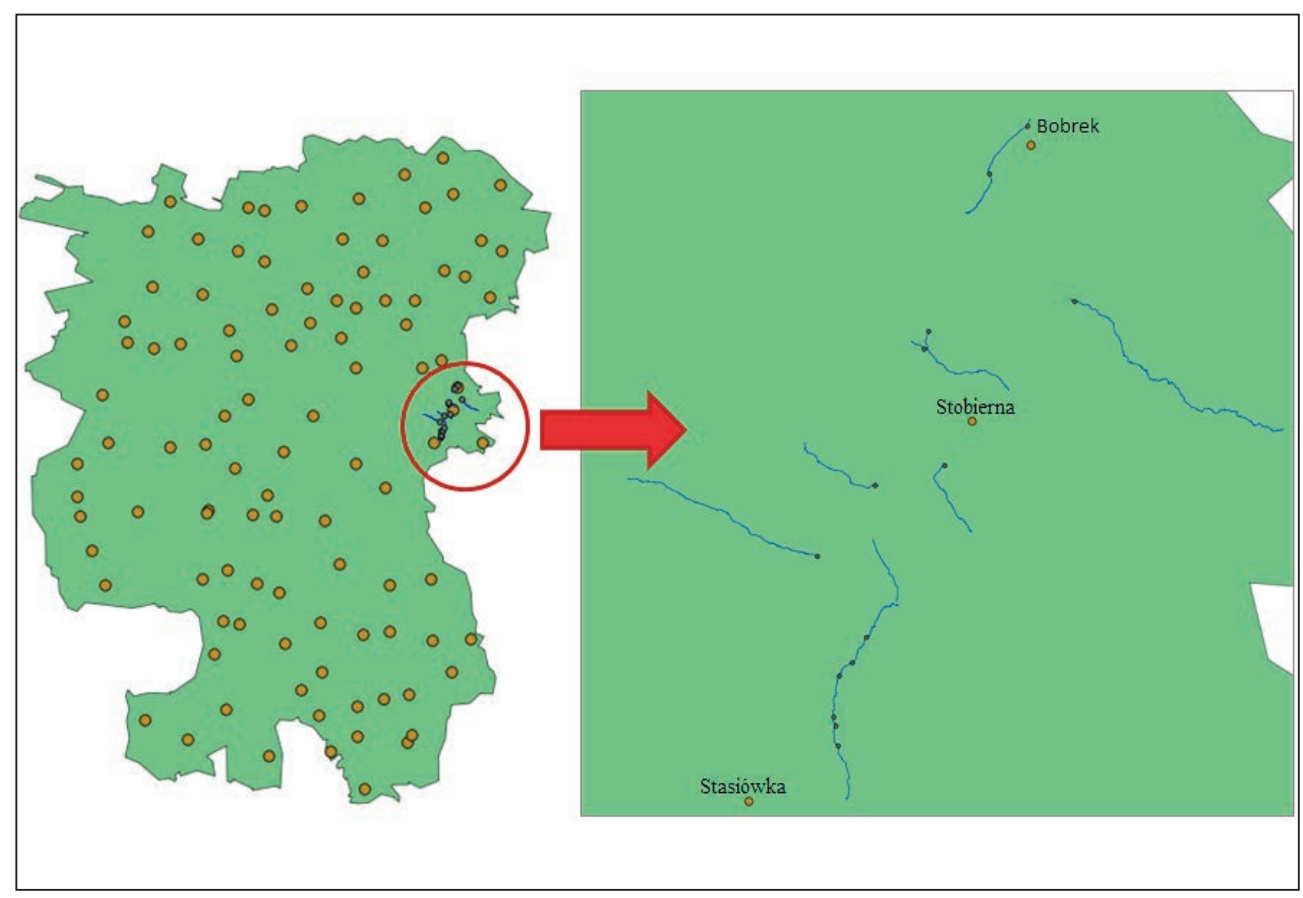

Fig. 2. Location of water courses measured with the GPS method with culverts on them

Measurements covered seven water courses as indicated by the Dębica Commune office staff. The selection criterion was a large number of complaints made by those people, who have the said water courses flowing through land plots they own. When water levels are high, or under heavy rain conditions, the water courses subjected to measurements make considerable damage, tearing away banks, washing out tree roots, and producing slopes and landslides.

In the course of performing field measurements, several such places were documented by means of photos. An example of damages and an image of a ravine and a landslide that emerged as a result of the water course activity is shown below Figure 3. 

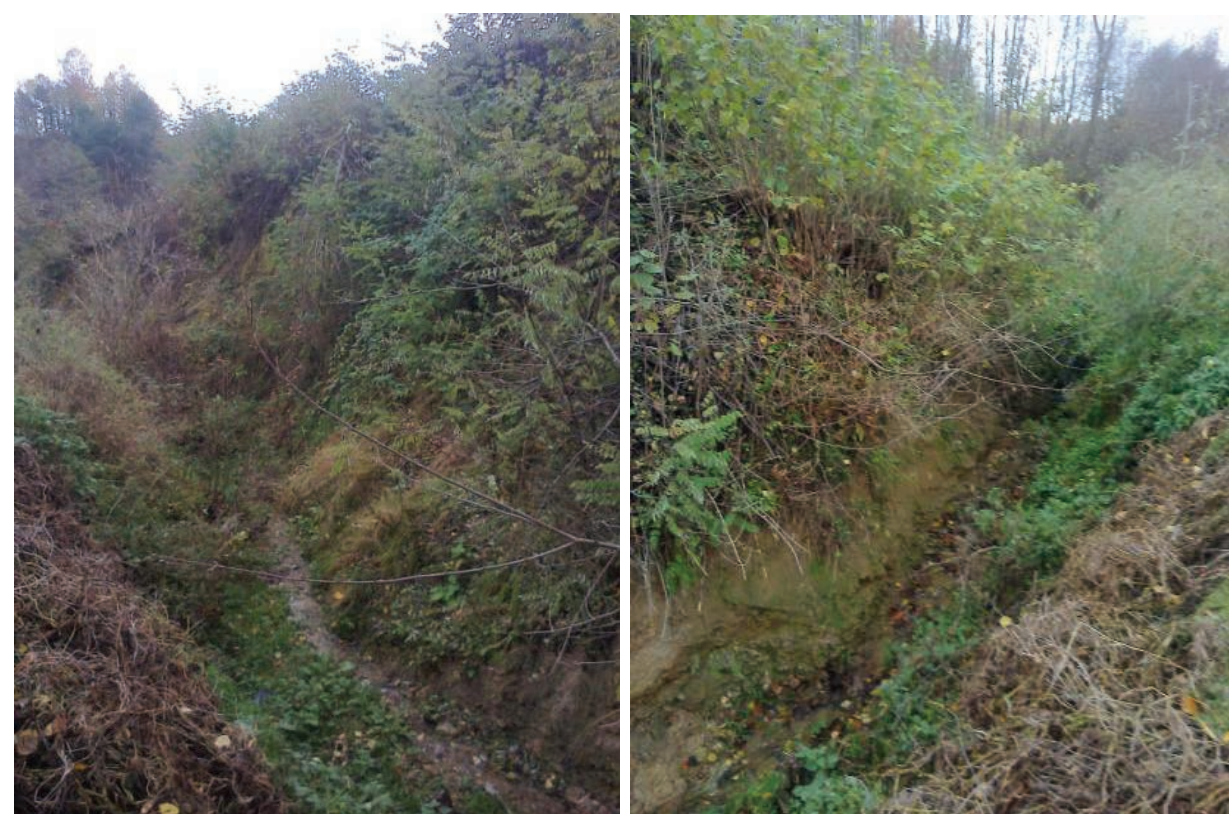

Fig. 3. Example of damages as a result of the water course activity

Source: [1]

\section{Updating and Data Integration}

The data base was created through the integration of data in different formats obtained from the above sources. To that purpose the GeoMedia Professional 6.1 software by Intergraph (limited-time version) and an open-source type program Quantum GIS (QGIS) 1.8.0 Lisboa were used.

Vector data obtained from the GPS receiver were subjected to editing and generalization, since the continuous recording of the water course track recorded places, in which it was necessary to pass by field obstacles. Also, a high concentration of nodal points was noticed, and they also were subjected to editing, Such concentrations were produced through e.g. slowing down or stopping the march along the water course. Also edited were places, in which water courses flow into the Zawadka River.

When creating databases of spatial data, vector data can be also useful. One can obtain them from the Web map portals, such as the OpenStreetMap. A high advantage of such vector maps is that they are constantly updated. For the needs of this paper, data including the area of the rural Commune of Dębica were downloaded. First, using the Internet browser, data for the area of the whole of Poland were downloaded from the www.geofabrik.de Website. Next, using the QGIS program tools, layers were trimmed to the County limits. The effect of the preliminary trimming 
of layers is shown in Figure 4a. The effect was not rewarding, since particular layers still were beyond the administrative boundaries of the Dębicki County. The obtained data had to be subjected to subsequent processing stages in order to get the desired effect. The obtaining of the effect of trimmed layers is possible through the use of geoprocessing tools. The project employed the product function, thanks to which one can get the common part of two selected objects. The principle of operation of the product tool is shown in Figure 4b.

a)

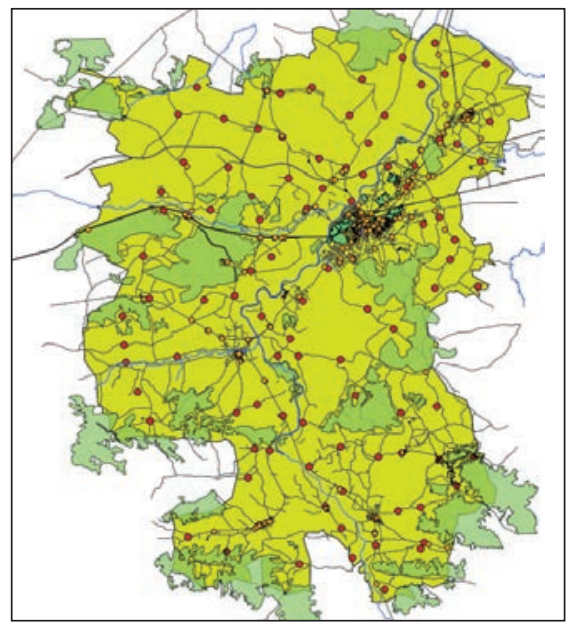

b)

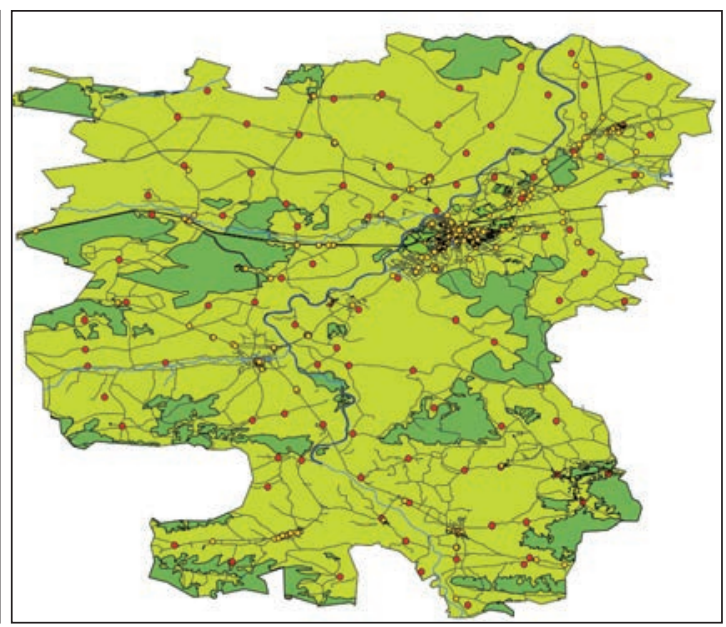

Fig. 4. Preliminary and precise trimmed layers to the administrative boundaries of the Dębicki County

Current cadastral data for the area of the rural Commune of Dębica were made available by the County Office in Dębica. The digital map provided was produced as a result of exporting vector data from the EWMAPA program to DXF format. The County Centre for Land Survey Documentation (PODGiK) published the map in 2000 system (EPSG:2179). For the project needs, data were imported from the file: gm_Dębica.dxf to the Geomedia Professional software. To that purpose, a tool for displaying vector files was used. Next, proper CAD software was selected to which the file belonged, as well as access path to the file: gm_Dębica.dxf. It is important to indicate the path of access to the coordinate system file, in which the data to be read are saved (EPSG:2179).

In advanced options, layers which contain plot boundaries and buildings and which have to be read in, were selected. Upon the end of data importing, it was noticed that the cadastral plot received from the PODGiK Centre (layer: "Dzialki Debica_PODGiK") did not cover the whole area under consideration. Considerable lacks in plot coverage are shown in figures below (Figs 5, 6). 


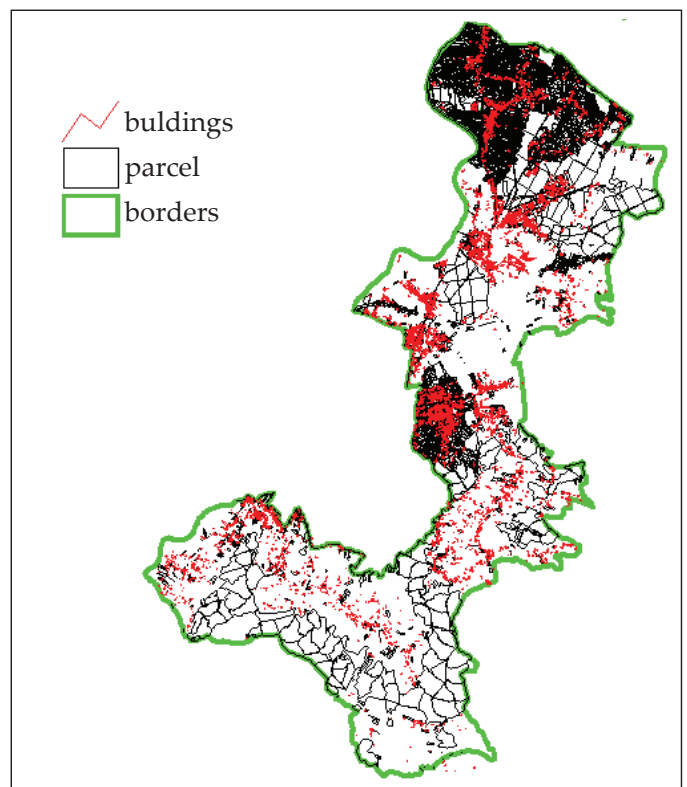

Fig. 5. Extent of the PODGiK cadastral data coverage for the Dębica commune area [1]

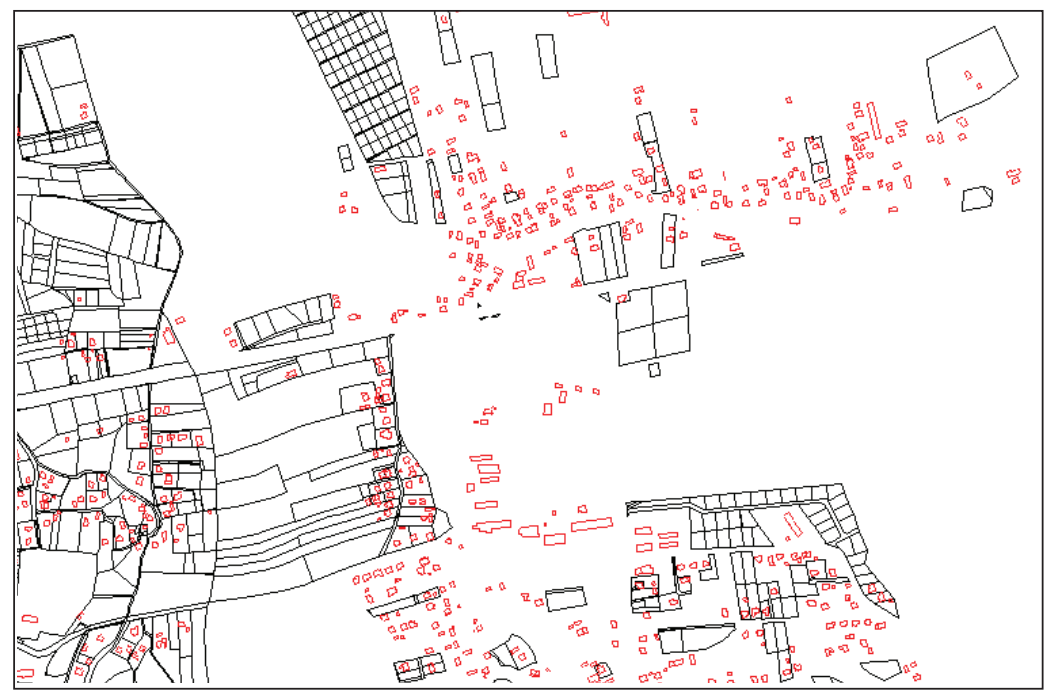

Fig. 6. A fragment of the map window with the PODGiK cadastral data [1]

In order to supplement the cadastral data, an option of downloading cadastral information made available by Geoportal was used. Downloading was effected by means of Web Feature Service (WFS) [9]. Query about vector data addressed to the "Get Feature" was made from the Internet browser level [11]. In the first turn, the 
query area was defined, or the so-called bounding box (BBOX): bottom left corner and upper right corner (in ymin,xmin, ymax,xmax format, coordinates in WGS84 system). There were 11 separate zones planned for the Commune of Dębica, since a larger BBOX returned errors (serves in a given moment cannot process so much information). An exemplary query for one of the zone looks like that: http://sdi.geoportal.gov.pl/wfs_dzkat/wfservice.aspx?service $=\mathrm{wfs} \&$ request $=$ getfeature $\& b b o x=4$ 9.948,21.322,49.967,21.501\&version=1.1.0\&typename=Dzialki\&srsname=EPSG:4326

After entering that query into any Internet browser, the WFS server returns a file, with XML extension (Extensible Markup Language), containing vector data saved in the form of GML (Geography Markup Language) markers [8].

The processed and updated layers were loaded into the Geoserver, which enables the publication data for example with network service WMS (Web Map Service) [10]. The Geoserver does not have a graphical tool that allows to change the method of displaying layers. Defining the display style is done by a text console using SLD (Styled Layer Descriptor). From the user knowledge is required structure and basic functions of the language. The styling of layers was quite difficult and laborious a process that requires special care preserve. However, suitable styling was necessary to ensure the clarity and transparency of displayed layers. For each layer an individual style was created. Thus, prepared spatial data have been made available as the WMS service. The developed service was then tested for interoperability by displaying it on different software platforms which are clients of network services (Fig. 7) and the connection of other available WMS services.

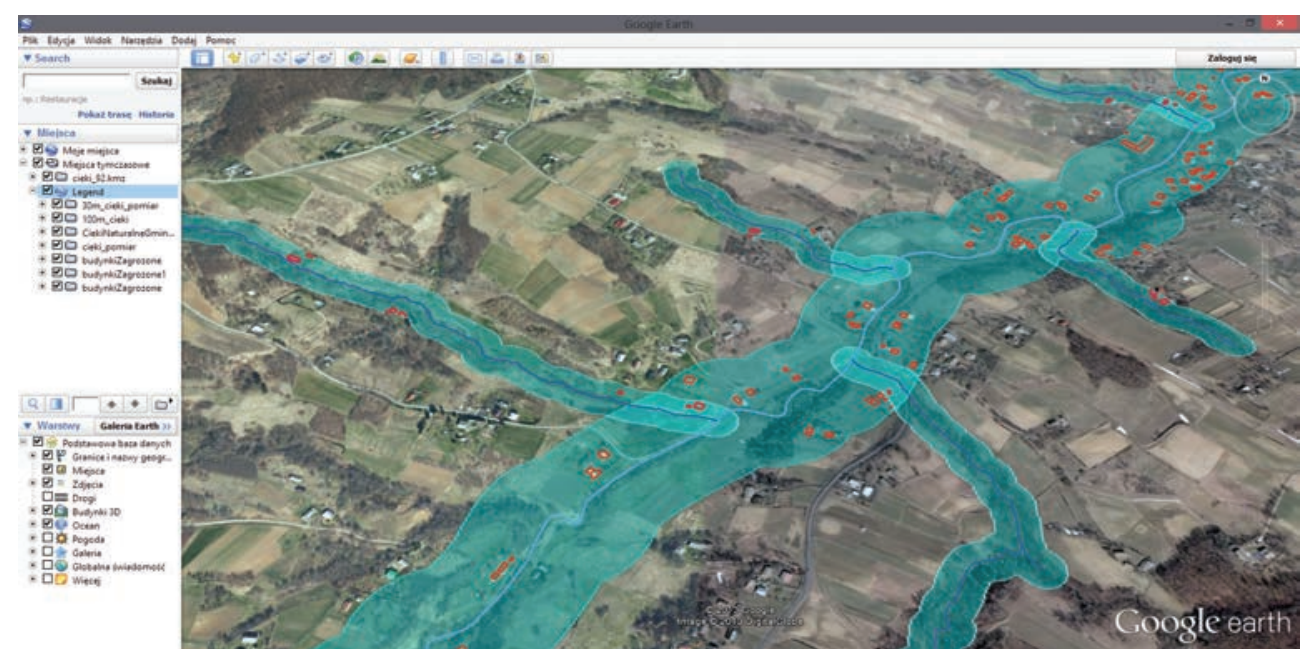

Fig. 7. A fragment of the map window of Google Earth application with the results of the analysis of hazard zones and endangered buildings location 
Integrated database Gm_Debica.mdb was used for spatial and attribute analysis $[3,14,15]$. First, a buffer zone was created with a width of $30 \mathrm{~m}$ around the watercourses and $100 \mathrm{~m}$ around natural watercourses. The result gave the flood hazard zone. In the next step it has been tested, which buildings are located in hazard zones. The analysis results saved in KML data format and presented in Google Earth (Fig. 8).

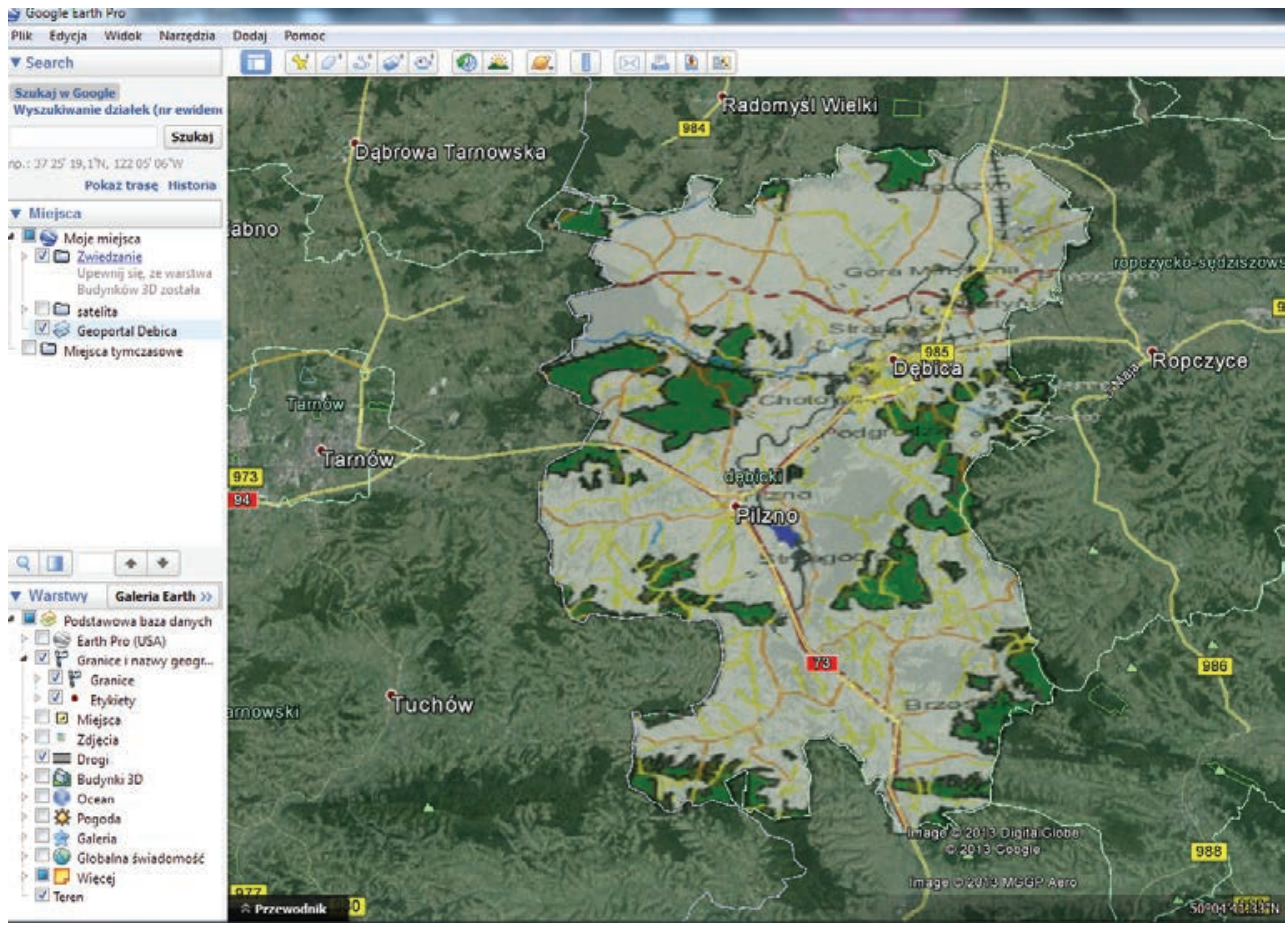

Fig. 8. WMS layer displayed using client network services - Google Earth

\section{Summary}

The resources of data, collected in the framework of the presented study, were integrated and complemented with the missing details of the terrain using the software Quantum GIS. Completing the missing elements were based on raster backgrounds in the form of ortho and data from the GPS measurement (measured water courses and culverts on them). Monitoring changes in surface water is of special significance for the correct operation of the flood prevention system, not only in the county, but also in the scale of the entire country. Currently, the tasks of each local administrative unit include developing systems of monitoring and modelling of spatial data. This has to accelerate the future predicting of floods and determining the endangered zones. Developing of a model, which would become basis modeling 
and decision-making in the event of threats of floods and flooding, is very expensive. It is the open-source software that makes an effort to meet our needs, since its functionality equals that of many commercial solutions, and, moreover, it is totally free of charge. The open source software tool proved to be fully adequate to testing the processes of spatial data integration and providing. It was useful from the stage of designing of the data for the study area, through the stage of their updating and publishing (using the Geoserver program), and finally display the final map in the form of the WMS (Web Map Service) layers as a service clients.

\section{References}

[1] Bochenek M.: Budowa i udostepnianie warstw tematycznych SIP gminy wiejskiej Dębica. Wyższa Szkoła Inżynieryjno-Ekonomiczna w Rzeszowie, 2013 [diploma thesis, unpublished].

[2] Bryndal T.: Parametry hydrologiczne wezbran spowodowanych krótkotrwatymi intensywnymi opadami deszczu w Polsce. Annales UMCS sec. B., vol. 65(1), 2010, pp. 43-71.

[3] Donaubauer A.: A multi-vendor spatial data infrastructure for local government based on OGC Web Services. FIG Working Week 2005 and GSDI-8, Cairo, Egypt, April 16-21, 2005.

[4] Długosz M., Gębica P.: Geomorfologiczne skutki oraz rola lokalnych ulew i powodzi w kształtowaniu rzeźby Pogórza Karpackiego (na przykładzie ulewy z czerwca 2006 r. w rejonie Sędziszowa Młp.). Landform Analysis, vol. 8, 2008, pp. 13-20.

[5] Dyrektywa 2007/2/We Parlamentu Europejskiego i Rady z dnia 14 marca 2007 r. ustanawiająca infrastrukturę informacji przestrzennej we Wspólnocie Europejskiej (INSPIRE). Dziennik Urzędowy Unii Europejskiej L 108/1.

[6] Dyrektywa 2007/60/WE Parlamentu Europejskiego i Rady z dnia 23 października 2007 r.w sprawie oceny ryzyka powodziowego i zarzadzania nim (Tekst majacy znaczenie dla EOG). Dziennik Urzędowy Unii Europejskiej L 288/27.

[7] Gudowicz J. Metoda modelowania zasięgu wód wezbraniowych na równinie zalewowej na przykładzie doliny Parsęty. Landform Analysis, vol. 8, 2008, pp. 29-32.

[8] ISO 19136:2007: Geographic information - Geography Markup Language (GML).

[9] ISO 19142:2010: Geographic information - Web Feature Service.

[10] ISO 19128:2005: Geographic information - Web map server interface.

[11] Iwaniak A.: Rola serwisów WMS WFS i generalizacji w upowszechnianiu informacji geograficznej. Roczniki Geomatyki, t. 3, z. 4, 2005, pp. 77-89.

[12] Mendelowski S.: W gminie Dębica. Roksana, Krosno, 2003.

[13] Mohammadi H., Rajabifard A., Williamson I.P.: Enabling spatial data sharing through multi-source spatial data integration. Proceedings of GSDI 11 World Conference, Rotterdam, 15-19 June 2009, pp. 1-19. 
[14] Mohammadi H., Binns A., Rajabifard A., Williamson I.P.: Spatial data integration. $17^{\text {th }}$ UNRCC-AP Conference and $12^{\text {th }}$ Meeting of the PCGIAP, Bangkok, Thailand, 18-22 September 2006.

[15] Montalvo U.W.: Mapping the Determinants of Spatial Data Sharing. Ashgate Publishing, 2003.

[16] Kondracki J.. Geografia fizyczna Polski. PWN, Warszawa 1981.

[17] Ustawa z dnia 26 kwietnia 2007 r. o zarządzaniu kryzysowym. Dz. U. 2007, nr 89, poz. 590.

[18] Woś A.: Klimat Polski. PWN, Warszawa 1999. 